\title{
Health, Sickness and Medical Services in Spain's Armed Forces c.1665-1700
}

\author{
CHRISTOPHER STORRS*
}

\section{Introduction}

The early modern era saw important changes in the character of warfare in Europe, including the development of larger, permanent armies and navies. Historians have studied many key aspects of what some call the "military revolution", ${ }^{1}$ whose character and timing have become a matter of debate ${ }^{2}$ but some important features of these emerging military communities remain largely unexplored. One subject which has not attracted the attention it merits is that of the health of soldiers and sailors and of medical provision in the new armies and navies. The issue has not been entirely neglected, either generally, ${ }^{3}$ or as it relates to specific states, ${ }^{4}$ but focused studies are rare. ${ }^{5}$ This is unfortunate, not least because of the importance attached to the issue of sickness and medical provision by contemporaries, and the value of medical provision as a sort of test case by which to measure the effectiveness of medical services and hence to contribute to the "military revolution" debate. For some historians the later seventeenth and eighteenth centuries saw

(C) Christopher Storrs 2006

Christopher Storrs, PhD, Department of History, University of Dundee, Dundee DD1 4HN, UK; e-mail: c.d.storrs@dundee.ac.uk

I wish to thank the Wellcome Trust for a grant which allowed me to spend one month researching this subject in Spain in the summer of 2002; and the anonymous referees of this journal for their invaluable comments on an earlier version. I, of course, am responsible for any remaining errors.

${ }^{1}$ See Geoffrey Parker, The military revolution: military innovation and the rise of the west 1500-1800, Cambridge University Press, 1988, passim.

${ }^{2}$ See Clifford J Rogers (ed.), The military revolution debate: readings on the military transformation of early modern Europe, Boulder, CO, Westview Press, 1995.

${ }^{3}$ See Andrew Cunningham and Ole Peter Grell, The four horsemen of the Apocalypse: religion, wars, famine and death in Reformation Europe, Cambridge University Press, 2000, pp. 92-199; Ole Peter Grell, 'War, medicine and the military revolution', in Peter Elmer (ed.), The healing arts: health, disease and society in Europe, 1500-1800, Manchester and Milton Keynes, Manchester University Press and the Open University, 2004, pp. 257-83; and Peter Elmer and Ole Peter Grell (eds), Health, disease and society in Europe,
1500-1800: a source book, Manchester and Milton Keynes, Manchester University Press and the Open University, 2004, pp. 256-81.

${ }^{4}$ For France, see Colin Jones, 'The welfare of the French foot-soldier', History, 1980, 65: 193-213; idem, The charitable imperative: hospitals and nursing in ancien regime and revolutionary France, London, Routledge, 1989; Lawrence Brockliss and Colin Jones, The medical world of early modern France, Oxford, Clarendon Press, 1997, pp. 689-700; and Guy Rowlands, The dynastic state and the army under Louis XIV: royal service and private interest, 1661-1701, Cambridge University Press, 2002, pp. 97-8. For England, see Charles G Cruickshank, Elizabeth's army, 2nd ed., Oxford, Clarendon Press, 1966, pp. 174-88; C R Butt, 'Army medical services in 1644', Journal of the Society for Army Historical Research (hereafter JSAHR), 1957, 35: 135; R V Steele, 'Marlborough's campaigns', JSAHR, 1921, 1: 126; G E Gask, 'A contribution to the care of the sick and wounded during Marlborough's march to the Danube in 1704 and at the battle of Blenheim', Journal of the Royal Army Medical Corps, 1922, 4: 274-88; and David Stewart, 'Some early military hospitals', JSAHR, 1950, 28: 174-9.

${ }^{5}$ Some general studies of early modern warfare do discuss medical provision and the need for it, see, for example, Frank Tallett, War and society in early modern Europe, 1495-1715, London, Routledge, 1992, pp. 105-12. 


\section{Christopher Storrs}

the first significant efforts to develop a structure of military and naval hospitals; ${ }^{6}$ for others, however, the extent of illness and the inadequacy of medical support services before the French Revolutionary and Napoleonic era suggests that many states failed to meet the organizational challenge posed by the growth of standing armed forces in the sixteenth, seventeenth and eighteenth centuries. ${ }^{7}$ What follows is an investigation of the extent and nature of illness, and the effectiveness of medical provision in the armies and navies of one major player of the period, Spain in the reign of the last Habsburg, Charles II (1665-1700). ${ }^{8}$

In the sixteenth and early seventeenth century Spain dominated western Europe by means of its formidable fighting forces-above all its famous tercios-which benefited from the development of precocious support services, including military hospitals, ${ }^{9}$ in part in response to the way disease depleted those units. ${ }^{10}$ By the second half of the seventeenth century, however, Spain was in retreat, militarily and territorially, before the rising power of Louis XIV's France. Unfortunately, but not entirely surprisingly, historians have shown little interest in Spain's armed forces-and in their support services-in this phase of apparent "decline". ${ }^{11}$ Indeed, although what we might call civilian medicine and related topics in Charles II's reign have attracted the attention of historians, ${ }^{12}$ military medicine in

\footnotetext{
${ }^{6}$ Matthew Smith Anderson, War and society in Europe of the old regime, 1618-1789, London, Fontana, 1988, pp. 107-8. Anderson's emphasis is on eighteenth-century developments.

${ }^{7}$ See Jürgen Luh, Ancien regime warfare and the military revolution: a study, Groningen, Instituut voor Noord- en Oost-Europese Studies/Institute for Northern and Eastern European Studies, 2000, pp. 48-63.

${ }^{8}$ The medical history of the king himself has attracted some interest, see Ramón García Argüelles, 'Vida y figura de Carlos II el Hechizado', II Congreso Español de Historia de la Medicina, Salamanca, 1965, vol. 2, pp. 199-232, and C Lisón Tolosana,

'Exorcismos en el Alcázar Real', in idem, La España mental, vol. 1: Demonios y exorcismos en los siglos de oro, Los Berrocales del Jarama, 2 vols, Madrid, Akal, 1990, pp. 143-202.

${ }^{9}$ Geoffrey Parker, The army of Flanders and the Spanish road, 1567-1659, Cambridge University Press, 1974, p. 167 (and passim); María José Rodríguez Salgado, Armada 1588-1988, London, Penguin Books, 1988, pp. 202-3; David Goodman, Power and penury: government, technology and science in Philip II's Spain, Cambridge University Press, 1988, pp. 238-50. For the navy, see Carla Rahn Phillips, Six galleons for the King of Spain: imperial defense in the early seventeenth century, Baltimore and London, Johns Hopkins University Press, 1986, pp. 177-80. According to W H Prescott (History of the reign of Ferdinand and Isabella, 1882, vol. 1, p. 198), the field hospitals provided by Ferdinand and Isabella during the
}

Granada War (1482-92) were the first example of their kind, cited by A C W, 'Medical care of soldiers', $J S A H R, 1925,4: 219$. However, rather surprisingly, this aspect of Spain's military establishment has not attracted the attention it merits. I A A Thompson, War and government in Habsburg Spain, 1560-1620, London, Athlone Press, 1976, for example, does not discuss medical services. Such neglect makes it the more difficult to compare the effectiveness of those services before and after 1660 .

${ }^{10}$ Charles V's invasion force of Provence (1536) was halved by disease and desertion: James D Tracy, Emperor Charles V, impresario of war, Cambridge University Press, 2002, p. 112.

${ }^{11}$ John Tate Lanning, The royal protomedicato: the regulation of the medical profession in the Spanish empire, with preface by J J Te Paske (Durham, NC, Duke University Press, 1985), largely ignores Spain itself (and Europe), Spain's armed forces, and the later seventeenth century; the same is true of Michael E Burke, The Royal College of San Carlos: surgery and Spanish medical reform in the late eighteenth century, with foreword by John Tate Lanning, Durham, NC, Duke University Press, 1977.

${ }^{12}$ See José Pardo Tomás and Alvar Martínez Vidal, 'El Tribunal del Protomedicato y los médicos reales (1665-1724)', Dynamis, 1996, 16: 59-90; María del Mar Rey Bueno and María Esther Alegre Pérez, 'El real laboratorio químico (1693-1700)', Dynamis, 1996, 16: 261-90; and Soledad Campos, 'Las enfermerías de damas y criadas en la corte del siglo XVII', Dynamis, 2002, 22: 59-83. 


\section{Sickness and Medical Services in Spain's Armed Forces c. 1665-1700}

the same era remains strikingly neglected. ${ }^{13}$ Yet Spain continued to maintain large numbers of men under arms-perhaps 100,000 in 1675-distributed among various armies: above all the Army of Flanders, the Army of Lombardy and the Army of Catalonia, the latter being the only one whose medical history in this period has attracted any real interest. ${ }^{14}$ These forces helped to ensure that Spain's empire remained largely intact in 1700, on the eve of the War of the Spanish Succession (1701-13). The following pages seek to throw some light on the medical history and provision of the armies - and the navies-which contributed to the remarkable resilience of the Spanish empire, or monarchy, in this testing period in view of some of the problems identified above.

This is no easy task. Military (and naval) hospitals in Spain are separately archived only from the eighteenth century. The historian seeking to reconstruct the medical services and associated subjects in Habsburg Spain is therefore obliged to rely on official material which covers a much larger and extremely diverse range of activities and institutions. What follows draws on the consultas - the formal discussions and recommendations in response to letters from administrators and commanders in the field and at sea regarding the state of their forces - of the Council of War, the Council of State, and the Council of the Cruzada (responsible for funding the galleys), which are now housed in the Archivo General de Simancas, outside Valladolid. These consultas have been supplemented by accounts relating to spending on the armed services found in the Contaduria Mayor de Cuentas series, also housed at Simancas.

Unfortunately, these records are too vast to permit an exhaustive investigation. Each year the Council of War's secretariat of the land forces generated about thirty legajosbundles-each containing about one hundred consultas (and accompanying documents), and the secretariat of the sea forces generated more than ten. In 1693, for example, the former produced thirty-four bundles and the latter twelve. In addition, and perhaps more importantly, the legajos of both Councils remain uncatalogued, making it impossible to identify legajos containing consultas on medical issues (rather than on matters of recruitment, supply, weaponry and so on). In order to overcome this problem, it was decided-besides using material already acquired in previous work in the relevant Spanish archives - to adopt a sampling approach, consulting the legajos for well-spaced groups of years (1673-76, 1683-86 and 1693-96, all years of war). Inevitably, this method has its drawbacks: it risks missing important developments in unsampled years, and may result in a rather episodic and impressionistic picture of health/sickness and medical provision in the Spanish armed forces. Nevertheless, it does make possible the identification of the extent and type of illness, the range of medical provision, its

\footnotetext{
${ }^{13}$ David Gentilcore, Healers and healing in early modern Italy, Manchester University Press, 1998, an otherwise splendid study of medicine in Spanish Naples focuses on "civil" medicine.

${ }^{14}$ See Antonio Espino López, Catalunya durante el reinado de Carlos II: política y guerra en la frontera
}

catalana 1679-1697, Barcelona, Universitat Autònoma de Barcelona, 1999, pp. 219-38; and Antonio Espino López, 'Enfermedad y muerte en el ejército de Cataluña durante la Guerra de los Nueve Años, 1689-1697', Dynamis, 1996, 16: 427-44. 


\section{Christopher Storrs}

success or failure - and the reasons for these - in Spain's armed forces in general in the last Habsburg decades. ${ }^{15}$ Although focused on Spain, it is hoped that elucidation of these subjects will enhance our knowledge and understanding of military medicine across early modern Europe as a whole, and of non-military medicine in Spain itself. ${ }^{16}$ A preliminary effort will be made to identify the scale of the medical problem, and the nature and cause of sickness; the focus will then shift to medical provision, and to the difficulties facing it-above all to the want of funding, the bugbear of Habsburg Spain.

\section{The Extent of the Problem}

We need first to gain some idea of the numbers of the sick and wounded in order to identify the scale of the problem and how it compared with other threats to manpower-notably loss by desertion-and also to assess both its implications and the success or failure of the military medical services. This is not easy, because, although it has been suggested that sickness and death rates were higher among soldiers than among the civilian population in general, ${ }^{17}$ the sources for the military-essentially relaciones, or summaries, sent to Madrid of the periodic muestras, or musters, conducted by officials of the army pay office, and other reports giving details of sick and wounded soldiers (and sailors) — are, again, patchy. In addition, they often fail to give precise figures of the number of enfermos, or sick. In the summer of 1676, the authorities of Fuenterrabía (an important garrison town on the Bay of Biscay, close to the border with France) complained to the king that, due to neglect, many of the soldiers recently levied for its garrison had fallen ill. Claiming there were far too many for the hospital there to accommodate, the authorities feared for both Fuenterrabía's security and the health of the townsfolk. Unfortunately, however they did not say how many sick there were. ${ }^{18}$ Even where a figure is given, it is not always separated from that for other sources of loss of men, notably desertion. In 1694, for example, 34 of a

\footnotetext{
${ }^{15}$ The only other studies of this subject are those by Antonio Espino López, cited in note 14 above. Lorraine White, 'The experience of Spain's early modern soldiers: combat, welfare and violence', War in History, 2001, 9: 1-20, covers the period to 1668. In addition, Luis Antonio Ribot García, La monarquía de España y la guerra de Mesina (1674-1678), Madrid, Actas, 2002, pp. 457-60, discusses medical provision for the troops during the Messina rebellion. As the titles suggest, these otherwise excellent studies are narrower in focus - in timescale, service arm and location - than the present paper.

${ }^{16}$ In general, see the references in Lanning, op. cit., note 11 above, and Burke, op. cit., note 11 above. Spanish demographic history has both depended upon and stimulated research into medical history; see the references in Pedro Ruiz Torres, 'El
}

país valenciano en el siglo XVIII: la transformación de una sociedad agraria en la época de absolutismo', in Roberto Fernández (ed.), España en el siglo XVIII: homenaje a Pierre Vilar, Barcelona, Crítica, 1985, pp. 132-248, on pp. 155-69, 229; Guy

Lemeunier, 'El reino de Murcia en el siglo XVIII: realidad y contradicciones del crecimiento', in ibid., pp. 289-341, on p. 298; and Eloy Fernández

Clemente and Guillermo Pérez Sarrión, 'El siglo

XVIII en Aragón: una economía dependiente', in ibid., pp. 565-629, on pp. 588-9.

${ }^{17}$ Tallett, op. cit., note 5 above, p. 105.

${ }^{18}$ Consulta of Council of War, 7 Aug. 1676, enclosing letter from the authorities in Fuenterrabía, Archivo General de Simancas [AGS]/Guerra Antigua [GA]/[legajo] 2346. 


\section{Sickness and Medical Services in Spain's Armed Forces c. 1665-1700}

total of 772 men of the tercio of Granada sent to Málaga to embark for Catalonia fell ill, died or deserted en route but our source does not quantify the different categories. ${ }^{19}$

Fortunately, some other records do more precisely distinguish between sick and wounded, revealing the extent of both of these and-our main concern-the fluctuating levels of sickness, measured by the number of those recorded as enfermo, or ill. The autumn and winter months were those in which illness was most evident, ${ }^{20}$ the spring and summer less so. In October 1690, as the campaigning season drew to a close, the reviews of the Army of Lombardy, revealed that, of a total of 2,912 cavalrymen, 98-more than 33 per cent-were enfermo. ${ }^{21}$ Sickness rates among the cavalry may have been greater than those in the infantry. In March and April 1691, according to another review carried out before the troops left their winter quarters to open the campaign, the Army of Lombardy included 1,274 sick infantrymen, more than 10 per cent of a total of 11,190 officers and men; ${ }^{22}$ by early June 1691, the number of enfermos among the infantry had fallen to 1,164 of a total of 15,416 officers and men-just 7.5 per cent. ${ }^{23}$ This problem also affected the Army of Flanders and that of Catalonia. In June 1693, the viceroy of Catalonia claimed that illness was rife in his army: there were 1,000 men in the military hospitals of Barcelona and Rosas. ${ }^{24}$ Some years later, in the spring of 1696 , another viceroy declared that there were usually 1,500 sick during the campaign; at that moment, before the campaign had started, there were 400 sick in his hospitals. ${ }^{25}$ Within a few months, with the campaign underway, there were twice that number, 800, in the Convento de Jesús hospital in Barcelona alone. ${ }^{26}$ The following year, in July 1697, of a total force of 4,140, 565 soldiers of the Spanish tercios in Catalonia were said to be ill-more than 10 per cent. ${ }^{27}$

\footnotetext{
${ }^{19}$ José Luis Navarro Pérez, 'Aportación económica y militar de la ciudad de Granada a las guerras del reinado de Carlos II', Chronica Nova, 1971, 6: 9-77, pp. 73, 62. In 1695, of 855 men of the same tercio who marched to Málaga, 24 were lost in the same ways.

${ }^{20}$ Espino López, 'Enfermedad y muerte', op. cit., note 14 above, pp. 438-9 (figures for the Army of Catalonia for 1689, 1692, and 1695).

${ }^{21}$ Relación de la muestra ... pasado en 9 de octubre a toda la cavallería del ejército, AGS/Estado [E], leg. 3413/67; Relación de la muestra ... pasado en 9 de octubre a toda la infantería del exército, AGS/E/3413/ 68. It also revealed that, of a total of 8,294 infantrymen, 2044 ( 25 per cent) were sick or wounded. On the Army of Lombardy, and its fluctuating size, see Christopher Storrs, 'The Army of Lombardy and the resilience of Spanish power in Italy in the reign of Carlos II (16651700), (Part I), War in History, 1997: 4: 371-98, and (Part II), War in History, 1998, 5: 1-22.

${ }^{22}$ Relación de la muestra que se ha pasado en las plazas a toda la infantería y cavallería deste exército en diferentes días de los meses de marzo y abril 1691, AGS/E/3414/213. Unfortunately, there is no record of the incidence of illness among the cavalry.

${ }^{23}$ Relación sumaria de la muestra ... passado ... a toda la infantería y cavallería del exército en 9 de junio
}

de 1691, AGS/E/3415/28. Again, nothing is said about the cavalry. In all Spain's armies, the proportion of infantry was greater than that of cavalry, although the proportion varied and that of the cavalry was generally increasing in the later seventeenth century.

${ }^{24}$ Consulta of Council of War, 27 June 1693, on Duke of Medina Sidonia to [?], 20 June 1693, AGS/GA/ 2913. The year 1693 was unusually bad in this respect, see Espino López, Catalunya, op. cit., note 14 above, p. 225.

${ }^{25}$ Consulta of Council of War, 12 May 1696, AGS/GA/3013.

${ }^{26}$ Don Juan de Alva Marquéz to [?], 26 June 1696, Barcelona, AGS/GA/3013.

${ }^{27}$ Relación que han dado los tercios de españoles de la gente de sus cuerpos que es en la manera siguiente, 20 July 1697, Archivo de la Casa Ducal de Alburquerque, Cuéllar, leg. 536/4. Among the Italian, Walloon and German infantry units of the Army of Catalonia it was much worse: there were 707 sickwell over 20 per cent — of a total of 3,266 men. This relación did not include those ill in the hospital. For rates of illness (and desertion) in various units of the Army of Catalonia between 1673 and 1695, see Espino López, 'Enfermedad y muerte', op. cit., note 14 above, pp. $430-1$. 


\section{Christopher Storrs}

Men often became ill a good distance from the frontline. In the summer of 1676, many of those recruited in Málaga and Murcia fell ill while waiting to embark at Cartagena; when 416 men and officers did at last take ship they left behind 80 in the hospital. ${ }^{28}$ Years later, in 1693, eight men in a contingent of well over 500 awaiting embarkation for Flanders at Cádiz either died or were dismissed because of their incurable illnesses. ${ }^{29}$ The journey to the front might also be difficult, whether by sea in small, crowded and often insanitary transport ships, or overland. In the summer of 1694, a tercio recruited in the Canaries for the Army of Flanders reached Ostend-via England - in a wretched state: of 433 men who had embarked in the Canaries, over 200 had fallen ill during the voyage, and 56 had either deserted (in England) or died. ${ }^{30}$ On dry land the journey-from the towns of Castile to a port of embarkation or to the front in Catalonia-could involve many days of marching, often in adverse conditions. ${ }^{31}$ In 1684, of 2,002 men (and 104 officers) recruited in Madrid for the five Castilian provincial tercios serving in Catalonia, 60 did not reach their destination: 16 deserted, 4 died and 40 ( 2 per cent of the original levy) fell ill en route. ${ }^{32}$

Sickness was not only a problem in Spain's armies; it also affected her navies, notably the Atlantic or High Seas Fleet, the so-called Armada del Mar Oceano, and the various squadrons (of Spain, Naples, Sicily, Sardinia and Genoa, that is the galleys hired from the Duke of Tursi) which made up Spain's Mediterranean galley fleet, and which averaged a total of twenty-eight to thirty vessels. In February 1675 there were 900 sick aboard the Atlantic fleet, which was participating in the reduction of the Messina revolt against Spanish rule, a figure which subsequently rose to $1,500 .^{33}$ Nine years later, in the spring of 1684, the number of sick on the Atlantic fleet then at Cartagena totalled between 700 and 800 ; this necessitated the construction of more than 250 additional beds in the hospital there, and also outstripped the resources of the neighbouring towns of Lorca and Murcia

\footnotetext{
${ }^{28}$ Consulta of Council of War, 14 Sept. 1676, on various letters from Don Antonio Martínez Valera, Governor of Cartagena, AGS/GA/2346. See also consulta of Council of War, 24 Sept. 1676, on letter from Don Pablo de Guzmán, 6 Sept. 1676, AGS/GA/ 3592. In 1689, 400 men levied in Galicia for the Army of Flanders fell ill and died because of the delays in organizing their transport to the Low Countries: Consulta of State, 11 Jan. 1691, on Marquis of Gastañaga to Charles II, 6 Dec. 1690, AGS/E/3884.

${ }^{29}$ Consulta of Council of War, 13 Jan. 1694, on letter from the Count of Montijo, 2 Jan. 1694, AGS/GA/ 2916. According to a report received only weeks later, 18 had died and 130 were sick: consulta of Council of War, 3 Mar. 1694, on letter from Montijo, 24 Jan. 1694, AGS/GA/2947.

${ }^{30}$ Consulta of council of State, 26 June 1694, and accompanying documents relating to muster at Ostend, AGS/E/3888. The men might have arrived in a worse state if the Spanish ambassador in England, the Marquis of Canales, had not arranged their transport to Flanders, see the contract he agreed with one Roland White, 27 April 1694, including details of the rations $-1.5 \mathrm{lbs}$ of bread or biscuit a day, $1 \mathrm{lb}$ of meat, $0.5 \mathrm{lb}$ of cheese, 2 pints of beer and fresh water for the men-to be enjoyed on the crossing, AGS/E/3887. For the
}

destructive effect of a sea journey on British troops going to Spain in a later conflict, see C T Atkinson, 'The cost of Queen Anne's war', JSAHR, 1955, 33: $174-83$, p. 180

${ }^{31}$ In 1693, recruits marching from Valladolid to embark at San Sebastián for Flanders faced fifteen days on the road, and those marching from Jaén (Andalucía) to Cádiz, eleven days, Presupuesto, 27 Nov. 1693, AGS/GA/2916. The march from León to Catalonia clearly involved a much longer, and more demanding, trail across Castile and Aragon.

${ }^{32}$ Consulta of Council of War, 24 May 1684, on a paper from Don Melchor Portocarrero, 18 May 1684, AGS/GA/2610. At the end of 1693, 66 recruits left Valladolid for Pamplona, leaving behind 16 othersjust over 20 per cent of the total-who had fallen ill and, it was hoped, would follow once they had recovered, consulta of Council of War, 13 Jan. 1694, on letter from Count of Montijo, 2 Jan. 1694, AGS/GA/2916. In 1694, the paymaster of recent levies in the realm of León spent more than 7,000 maravedis on the treatment of the sick, and another 680 on the burial of two recruits recently arrived from neighbouring Asturias, AGS/Contaduría Mayor de Cuentas [CMC]/Tercera Época [3a]/3042/29.

${ }^{33}$ Ribot García, op. cit., note 15 above, p. 217. 


\section{Sickness and Medical Services in Spain's Armed Forces c. 1665-1700}

which were called on to help shoulder the burden. ${ }^{34}$ As for the galleys, in the spring of 1664, more than 100 men-the equivalent of 50 per cent of the complement of one galley-were said to have died since June of the previous year aboard the five galleys of the Duke of Tursi. ${ }^{35}$

Just as we cannot always accept at face value official figures on the number of soldiers and sailors in service, so we cannot accept without question the official numbers of enfermos. Some at least of those recorded as ill were probably malingerers. In the summer of 1692, a trawl through the general hospital (of Santa Cruz or Santa Creu) at Barcelona, resulted in a number of those soldiers said not to be genuinely sick being ordered back to their regiments. ${ }^{36}$ Some of those who were acknowledged to be ill were not so much sick as aging and suffering a decline in their physical capabilities which rendered them less fit for active service. In 1694, for example, the alférez, or junior official, Don Andrés Segarle petitioned for a ración de enfermo, or sick ration, in the Hospital Real, claiming that he had served in the Spanish galleys for more than twenty-four years and was now too shortsighted to continue. ${ }^{37}$ Some of the sick may not have existed at all. In December 1695 there were said to be an unspecified number of sick soldiers in the Army of Catalonia both in the military hospital and in private houses. But there was some suspicion that at least some of these enfermos were the invention of officers fraudulently seeking to supplement their own pay. ${ }^{38}$ The existence of royal hospitals in which the sick and wounded could be both properly cared for and also counted was thus in part at least a weapon in the constant struggle waged by the king and his ministers against the corrupt practices of their own officers.

Despite these reservations about the real extent of illness, sickness among Spain's soldiers and sailors was a serious problem for commanders in the field and for their masters in Madrid who depended on the effectiveness of those forces to achieve their strategic objectives: without sufficient men to pull the oars, for example, the galleys - the lifeline of the Spanish empire in the Mediterranean-simply could not put to sea. ${ }^{39}$ Sickness could reduce the galleys' operational effectiveness. In the summer of 1693, the level of illness among the oarsmen of the two galleys of the squadron

${ }^{34}$ Consultas of Junta de Armadas, 6 April and 6 May 1684, AGS/GA/3709. There were said to be more than 500 sick in the naval hospital at Cádiz in May 1684. This was certified by the veedor general of the Armada, as part of the relación de servicios of Don Juan Guerrero, protomédico of the Atlantic fleet, Madrid, 23 Sept. 1688, AGS/GA/Servicios/42.

${ }^{35}$ See certificate of the number of deaths aboard the galleys of the Duke of Tursi's squadron since 9 June 1663, Barcelona, 27 March 1664, AGS/E/3611/113. They included 42 forzados (convicted criminals sentenced to the galleys), 35 buenas boyas (volunteers), and 27 slaves, a total of 104. In January 1675 the capitana (flagship) of the Spanish galley squadron alone had more than 130 sick, besides many convalescents, Ribot García, op. cit., note 15 above, p. 217. p. 256.

${ }^{36}$ Espino López, Catalunya, op. cit., note 14 above,

${ }^{37}$ Consulta of Junta de Galeras, 3 April 1694, on report of Don Andrés Segarle, AGS/GA/3906. The junta consulted the commander of the galleys, who supported the request and sent a certificate from the doctor and surgeon of the galleys confirming the claim.

${ }^{38}$ Consulta of Council of War, 4 April 1696, on letters from the Marquis of Gastañaga, 9 and $11 \mathrm{Dec}$. 1695 , and a letter from the veedor general of the Army of Catalonia (on recent muster of troops), 15 Dec. 1695, AGS/GA/3011.

${ }^{39}$ In 1664, the Duke of Tursi claimed that he could not execute royal orders to detach two of his galleys to carry money to Italy because of the shortage of oarsmen, due to the many deaths aboard during their sojourn off the Spanish coast, consulta 


\section{Christopher Storrs}

of Sardinia-on 11 August, there were 94 being treated in the hospital of the arsenal of Naples and 60 convalescents - obliged them to return to Sardinia rather than accompany the other galleys to Catalonia for the campaign. ${ }^{40}$

Ill health was not the only reason why numbers dwindled. Military and naval historians have tended to focus on the loss of military manpower resulting from desertion. ${ }^{41}$ However, while this generally caused the loss of more men than did sickness, it was not always so. ${ }^{42}$ In addition, fear of sickness and death no doubt explained why some-many-did desert. ${ }^{43}$ Commanders and ministers in other states faced similar problems. ${ }^{44}$ However, Spain-and above all Castile, the traditional reservoir from which Spain's armies were supplied within the Iberian peninsula-had suffered a major demographic setback in the early seventeenth century. Population figures in the later seventeenth century may have been recovering, but the reserves of manpower from which to make good any losses, whatever their origin, ${ }^{45}$ were certainly less than in some other states-notably Francethereby contributing to the overall decline in the size of Spain's armed forces.

\section{The Nature and Origin of the Problem}

Illness was therefore a serious problem. But the sick were no simple category; on the contrary, soldiers and sailors needed medical treatment for a great variety of reasons. Some of these were more obviously "military" than others. In addition, the military community was a large and diverse body and some types of soldier were more prone to need treatment - of whatever kind - than were others.

When seeking to explain why those in Spain's armed forces between 1665 and 1700 needed medical assistance, we must distinguish between those wounded in action-by

of Council of State, Madrid, 19 May 1664, AGS/E/3611/109.

${ }^{40}$ Consulta of State, 7 Nov. 1693, AGS/E/3226/13, on various documents, including the certification of the extent of illness by Doctor Jaime Sayo, médico of the Sardinian galleys, Naples, 11 August 1693. According to the Savoyard minister in Naples, many of the sick later died: Gian Battista Operti to Marquis of San Tommaso, 7 July 1693, Archivio di Stato di Torino [AST], Lettere Ministri [LM], Napoli o Due Sicilie, mazzo 5. In 1695, too, the departure of the Neapolitan galleys from Naples was delayed by the lack of men, many of whom were ill. It was feared that those galleys would not get away until end May at the earliest, after the opening of the campaign season, with important implications for Spain's ability to prevent the French seizing the initiative in the Mediterranean, Operti to San Tommaso, 25 Feb. 1695, AST/LM/Napoli, m. 6.

${ }^{41}$ Anderson, op. cit., note 6 above, pp. 128-30.

${ }^{42}$ Between 1673 and 1695 , losses sustained by various units in the Army of Catalonia through desertion on all but one occasion (1674-75) for which we have data were greater than the losses sustained through illness, but whereas in 1695 (tercio of Don Joan Copons) the respective contributions were 74.6 per cent and 17.8 per cent, in 1694-95 (tercio of the city of Barcelona) they were 30.7 per cent and 28.2 per cent, Espino López, 'Enfermedad y muerte', op. cit., note 14 above, p. 431. Unfortunately, want of data for all units over long periods makes sustained and meaningful comparison between different units-and for the same unit over a long time-virtually impossible.

${ }^{43}$ This happened in Catalonia in 1639, see Luis R Corteguera, For the common good: popular politics in Barcelona, 1580-1640, Ithaca and London, Cornell University Press, 2002, p. 151.

${ }^{44}$ See Rowlands, op. cit., note 4 above, pp. 208-12.

${ }^{45}$ See Vicente Pérez Moreda, Las crisis de mortalidad en la España interior siglos XVI-XIX, Madrid, Siglo XXI, 1980, pp. 107-12; and Bartolomé Yun Casalilla, 'Del centro a la periferia: la economía Española bajo Carlos II', Studia Historica. Historia Moderna, 1999, 20: 45-76, on pp. 51-3. 


\section{Sickness and Medical Services in Spain's Armed Forces c. 1665-1700}

enemy grenade, shot or blade ${ }^{46}$ - and those who were otherwise sick, although the distinction cannot always be rigidly maintained, as a wound might result in some other type of infection or illness. A report on those being treated in the general hospital in Barcelona in July 1697 was clear on this: of a total of 392 inmates, it identified 225 wounded (218 infantrymen and 7 cavalrymen) and 167 sick. $^{47}$

It has been suggested that changes in the way war was fought in the later seventeenth century-above all the more effective use of fire-power-made for both new and more serious types of wound, and an increase in casualty rates. ${ }^{48}$ Certainly, Spain's armed forces were frequently in action, defending Spain and its empire against Louis XIV, the forces of the king of Morocco (in north Africa), and others; and action meant casualties. In north Italy, in 1690 and again in 1693, the Army of Lombardy suffered when the forces of Spain and its ally the Duke of Savoy were defeated in battle by those of the French king. ${ }^{49}$ Even success could be costly: in 1692, the Army of Lombardy incurred further casualties during the allied invasion of Dauphiné ${ }^{50}$ The Army of Flanders also suffered in action. In 1674, the number of Spanish dead and wounded at the bloody battle of Seneffe was put at over 3,000; and in 1678 the Spanish forces again incurred substantial losses at the battle of Saint Denis. ${ }^{51}$ The Army of Catalonia, too, was plagued by losses: the number of dead, wounded and deserters recorded after defeat at the hands of Louis XIV's forces at the battle of the river Ter (1694) totalled 3,255. ${ }^{52}$

Identifying the extent and nature of wounds is not always easy, although the relaciónes de servicios, accounts of services of individual soldiers prepared when they sought or were being considered for an appointment, or other merced, or royal favour, often provide useful information in this respect. ${ }^{53}$ Death and wounding in action-and some peculiarly military conditions such as trench foot and shell shock ${ }^{54}$-were, however, less common than other

\footnotetext{
${ }^{46}$ Don Manuel del Castillo Alvarado was said to have been wounded by a grenade at Puigcerda according to a consulta of the Council of War, 1699, AGS/GA/3908, proposing candidates for the vacant post of sargento mayor in the tercio of Don Juan Fernández de Aguirre. The same consulta informs us that Don Gregorio Calderón was wounded at the siege of Camprodon, and Don Juan Ambrosio Enríquez y Zarate at the siege of Barcelona (1697)

${ }^{47}$ Relación de los oficiales y soldados que los tercios y companias de infantería y cavallería del exto se hallan heridos en el Hospl. Genl. de Sta. Cruz de Barcelona el día 21 de jullio de 1697, Archivo de la Casa Ducal de Alburquerque, Cuéllar, leg. 536/4. The units with most wounded were the permanent (or regular ones) rather than those of the Principality of Catalonia and of Barcelona.

${ }^{48}$ Cunningham and Grell, op. cit., note 3 above, p. 125; Grell, op. cit., note 3 above, pp. 258-60; David G Chandler, 'Armies and navies', in J S Bromley (ed.), The new Cambridge modern history, vol. 6: The rise of Great Britain and Russia, 1688-1715/25, Cambridge University Press, 1970, pp. 741-62, on p. 749.
}

\footnotetext{
${ }^{49}$ Seventy cavalrymen were said to have died and a further 191 to have been wounded at the battle of Staffarda in 1690: consulta of State, [20 Sept.] 1690, AGS/E/3412/106 and 110. Spain's losses in the battle of Marsaglia in 1693 totalled more than 3,000: AGS/E/ 3656/3, 6 and 7. The heaviest losses in 1693 were sustained by the (Spanish) tercios of Lombardy, Naples and Savoy.

${ }^{50}$ See Marquis of Leganés to Charles II, 17 Aug. 1692, AGS/E/3417, 86 giving an account of the progress of the allies and telling of 40 Spanish casualties (dead and wounded) in the siege of Embrun.

${ }^{51}$ See Relación, printed in Colección de documentos inéditos para la historia de España, 95, Madrid, 1890, pp. 59, 72-7.

${ }^{52}$ Espino López, Catalunya, op. cit., note 14 above, p. 137.

${ }^{53}$ The relación de servicios of the captain, Don Juan de Torres Mantia, Madrid, 30 Jan. 1697, AGI/Panamá/ 181, fol. 102. The captain had received a bullet wound in the ankle.

${ }^{54}$ Parker, op. cit. note 9 above, p. 169; Grell, op. cit., note 3 above, p. 275
} 


\section{Christopher Storrs}

ailments. ${ }^{55}$ As for the sick (rather than the wounded), it is often difficult to be precise about the nature of the illness or its cause. There was frequently little difference between the infections of soldiers and those of civilians. ${ }^{56}$ In the spring of 1693, many new recruits in Naples were said to be in hospital with "the French disease", i.e. venereal infection. ${ }^{57}$ The troops might sometimes simply be the victims of a general contagion affecting the entire (civilian) population. This was, for example, the case at Cartagena-a major naval base and embarkation point-where in 1676 some soldiers were struck down by the plague then entering Spain; as late as September there were still said to be 6 soldiers in the infirmary there affected by plague. ${ }^{58}$ Of course, as large communities, armies (and fleets, even squadrons of ships or galleys) were ideal locations for the spread of disease. In the Spanish Low Countries, in 1693 the governor-general reported that his troops had been greatly reduced by an epidemic which had dogged them throughout the campaign. ${ }^{59}$

However, the vulnerability of the troops was often exacerbated by the authorities' failure properly to provide for them. We have already seen that delays in embarking men and the sea journey or overland march could result in illness and even death. The campaign season was also very demanding because of the combination of strenuous activity, often in difficult climatic conditions, lack of rest, stress, and-again-inadequate provisions. ${ }^{60}$ In October 1667 the governor of the Spanish Low Countries informed Mariana of Austria (who acted as regent during Charles II's minority, between 1665 and 1675) that sickness, fatigue, the continued marches and "miseries" of campaigning meant that he now had only 2,000 Spaniards under his command. ${ }^{61}$ Nor were these problems confined to those operating on land. The men on the galleys were also likely to fall ill during or after prolonged exertion, ${ }^{62}$ especially in difficult weather well into the campaign season: a demanding sea voyage late in the previous year seems to have been a factor in the unusual levels of illness in the fleet in the spring of $1684 .^{63}$

\footnotetext{
${ }^{55}$ Tallett, op. cit., note 5 above, pp. 106, 108.

${ }^{56}$ Ibid., p. 108.

${ }^{57}$ Operti to San Tommaso, Naples, 13 Mar. 1693, AST/LM/Napoli, m. 5.

${ }^{58}$ Real cedula, 17 Oct. 1676 , following consulta of Council of War, 2 Oct. 1676, on letter of royal officials at Cartagena, 22 Sept. 1676, AGS/GA/2360. On this plague, see Henry Kamen, 'The decline of Castile: the last crisis', Econ. Hist. Rev., 1964, 17: 63-76.

${ }^{59}$ Max Emmanuel of Bavaria to Charles II of Spain, 23 Oct. 1693, Brussels, in Henri Lonchay, et al. (eds), Correspondance de la cour d' Espagne, vol. 5: Précis de la correspondance de Charles II (1665-1700), Brussels, Académie Royale de Belgique, 1935, p. 597.

${ }^{60}$ For contemporary thinking on what soldiers could put up with, see Antonio Espino López, 'Oficiales catalanes en el ejército de los Austrias, 1635-1700', Cuadernos de Historia Moderna, 2000, 24: 31-53, p. 37.

${ }^{61}$ Consulta of council of State, 11 Nov. 1667, on Constable of Castile to Queen Regent, 20 Oct. 1667, $\mathrm{AGS} / \mathrm{E} / 2106$
}

\footnotetext{
${ }^{62}$ In 1661, 200 men were said to have died aboard the Genoese galleys in the Spanish service following demanding voyages to Oran and elsewhere, and, given the many sick on board many more were also expected to die, Diego de Laura (secretary) to Don Luis de Oyanguren, Genoa, 20 Dec. 1661, AGS/E/3610/75. See also, Duke of Nájera to [Charles II?], Naples, 25 Feb. 1695, AGS/E/3326/17. In 1662 the Duke of Tursi claimed that he could not execute the king's order to detach two of his galleys to transport Cardinal Colonna to Spain because he had already given two galleys to carry the Count of Peñaranda, and the rest of his crews were all sick after the exertions of a fourteen-month voyage, Don Carlo Doria Carretto [Duke of Tursi] to Philip IV, Genoa, 10 Oct. 1662, AGS/E/3611/160. The Duke added that, if he were to sail, he would have to put into French ports where there was contagion, such that he feared he would then not be allowed into Spanish ports.

${ }^{63}$ Consultas of Junta de Armadas, 6 April and 6 May 1684, AGS/GA/3709.
} 


\section{Sickness and Medical Services in Spain's Armed Forces c. 1665-1700}

Poor quality or insufficient food was another distinctive cause of illness. In 1680, a change in the daily diet of the men at the oars of the galleys apparently resulted in an increase in the number of sick. ${ }^{64}$ Unfortunately, the sources rarely distinguish between malnutrition and food poisoning as the cause of illness, while there was always scope for disagreement about the decisive element in any particular case. In 1695, more than 200 Portuguese soldiers - sent to defend Ceuta, one of Spain's north African garrisons, against the king of Morocco-fell ill. This was attributed to the poor quality bizcocho-a sort of cake-the Portuguese had received (whereas the Spanish troops had good quality pan de munición, or standard issue bread). ${ }^{65}$ According to the bishop of Ceuta, who investigated the outbreak, the bizcocho had arrived late_and rather damp-because of stormy seas. Then, because of a lack of storage space, some of the bizcocho had been housed in the cathedral sacristy, where gesso was also stored for building work. However, according to the doctors who also consulted, the real problem was not the food but the poor weather and the constant fatigues - marches, night watches and so on-necessitated by the attacks of the forces of the king of Morocco. ${ }^{66}$ In extreme weather, both hot and cold, as well as wet, inadequate accommodation and a lack of wood for fires (both for heating and cooking) also threatened the well-being and health of the troops. ${ }^{67}$

Some among the troops were particularly vulnerable. Those most affected were primarily — but not only - the rank and file. As might be expected, new recruits, as opposed to experienced and hardened veterans, were most likely to fall ill. According to one report of 1684 all the newly raised men had fallen ill three or four times. ${ }^{68}$ Raw recruits were, not surprisingly, less able to support the rigours of campaigning, as was evident in 1684 in Catalonia. ${ }^{69}$ This was one good reason for the widespread preference for veterans-one not peculiar to Spanish commanders-men who were used to, and better able to overcome, the hardships of army life. Unfortunately, however, the shortage of military manpower and the resort to what was little short of impressment by Charles II's ministers to fill the ranks, ensured that the latter included many with little experience of or inclination for the military life. ${ }^{70}$ But even veterans fell ill if sufficiently stretched and insufficiently cared for, as happened in the winter of $1677-78$, in Sicily. ${ }^{71}$ Others who were vulnerable included foreign troops in the Spanish service, who were less used to the climate, above all the summer heat, and to the foods of the peninsula. ${ }^{72}$

\footnotetext{
${ }^{64}$ Cesáreo Fernández Duro, Disquisiciones náuticas, Madrid, Imprenta de Aribau, 1877 (facs. ed., Madrid, 1996, Ministerio de Defensa, Instituto de Historia y Cultura Naval), vol. 2, pp. 134-5.

${ }^{65}$ Consulta of State, 7 May 1695, on Marquis of Sentmenat to Charles II, Lisbon, 26 April 1695, AGS/E/ 4041, reporting the complaint of the Portuguese Secretary of State; Count of Frigiliana to [?], 3 July 1695, enclosing report from the Portuguese envoy in Madrid, AGS/E/4041.

${ }^{66}$ Consulta of State, 5 July 1695 , on report of the Marquis of Valparaíso, and certificates of doctors, Ceuta, 10 June 1695, and veedor, Ceuta, 11 June 1695, all in AGS/E/4041.

${ }^{67}$ Ribot García, op. cit., note 15 above, p. 458.
}

\footnotetext{
${ }^{68}$ Consulta of Council of War, 19 Oct. 1684, AGS/ GA/2609

${ }^{69}$ Espino López, Catalunya, op. cit., note 14 above, pp. $59-60$

${ }^{70}$ Between 1695 and 1697 , Charles II imposed a fixed levy ( 1 per cent of households in $1695,0.5$ per cent in 1696 and 1.25 per cent in 1697) to recruit the Army of Catalonia, Christopher Storrs, The resilience of the Spanish monarchy 1665-1700, forthcoming, Oxford, Clarendon Press, 2006, pp. 40-45.

${ }^{71}$ Ribot García, op. cit., note 15 above, p. 463.

${ }^{72}$ This may well explain the contrasting rates of illness between Spanish and non-Spanish units in the Army of Catalonia in the summer of 1697, as in note 27 above. Earlier, in 1662, Scots troops raised for service
} 


\section{Christopher Storrs}

Soldiers and sailors fell ill for many different reasons, not all of them "military" in origin. These various causes had important implications for the incidence and timing of sickness and need for medical treatment. However, whether obviously military or not, perhaps the most important threat to the health and well-being of the armed forces was the inadequacy of provision for them on the part of the military (and other) authorities.

\section{Medical Services}

Throughout Europe, writers on military affairs recognized the need to care for soldiers, and to provide hospitals for them, ${ }^{73}$ as did senior military officials and policy-makers in Spain and its empire. This was a matter both of justice and prudence. On the one hand, commanders and ministers acknowledged an obligation to those who had suffered in the service of the king: ${ }^{74}$ on the other, in a Spain where (as we have seen) population was at best stagnant, and recruitment increasingly difficult, inadequate or poor treatment might result in the illness-even the death-of tens, hundreds, and over a generation even thousands of servicemen, soldiers, sailors, oarsmen and so on, who would be hard to replace. Neglect might also encourage desertion and discourage others from joining up. Ultimately, wastage though sickness might paralyse the king's armed forces, and jeopardize the defence of the monarchy, or component territories. Commanders and officials therefore gave thought and priority to the cure of the sick and wounded, ${ }^{75}$ whose treatment was the responsibility of an established and complex structure of medical provision.

A network of military and naval medical services already existed in 1665 . The senior ranks of each regiment included a surgeon, although his salary was relatively low. ${ }^{76}$ As for the naval forces, each galleon had-or was supposed to have-its own complement of médico (doctor), cirujano (surgeon), and boticario (pharmacist), according to regulations dating from the later sixteenth century. ${ }^{77}$ Each galley too, had its own doctor and surgeon, as did the various galley squadrons. ${ }^{78}$ These men were frequently overseen by the protomédico, effectively the chief medical officer of the unit and/or realm from which it originated, although practice varied between the various territories of the monarchy. ${ }^{79}$ In

in the Iberian peninsula had been warned on their arrival in Portugal against excessive consumption of local wine and fruit, $\mathrm{P} \mathrm{H}$ Hardacre, 'The English contingent in Portugal, 1662-1668', JSAHR, 1960, 38: 112-25, p. 114.

${ }^{73}$ The Earl of Orrery, A treatise on the art of war, London, 1677, pp. 53-4, cited by J H L, 'Medical care of soldiers', JSAHR, 1925, 4: 58.

${ }^{74}$ Consulta of Council of War, 7 Oct. 1676, AGS/ GA/2436, and consultas of Junta de Armadas, 6 April and 6 May 1684, AGS/GA/3709.

${ }^{75}$ Duke of Nájera to [Charles II?], Naples, 25 Feb. 1695, AGS/E/3326/17.

${ }^{76}$ In 1684, the officials of each of two new tercios raised in the kingdom of Navarra included a surgeon who enjoyed a salary of 150 reales, one of the lowest: Relazión de lo que importa un mes de sueldo sin desquento del terzio, AGS/GA/2608. According to the agreement for three Württemberg regiments to serve in Milan, concluded in 1690, the surgeon would receive 9 scudi, less than the captain, alférez, sergeant, cabo (corporal) or escrivano (clerk) and just over double what a simple soldier received: AGS/E/3416, 167.

${ }^{77}$ Phillips, op. cit., note 9 above, p. 139.

${ }^{78}$ The galley squadron supplied on contract by the Duke of Tursi had a hospital galley based in the Genoa arsenal, see Don Carlo Doria Carretto, Duke of Tursi, to Philip IV, Barcelona, 4 Mar. 1664, AGS/E/3611/99.

The five galley squadrons were those of Spain, Naples, Sicily, Sardinia, and Tursi.

${ }^{79}$ The Castilian Tribunal of the Protomedicato acquired wide responsibilities, including the appointment of medical personnel to the armed forces, but represented a different model to that of Aragon 


\section{Sickness and Medical Services in Spain's Armed Forces c. 1665-1700}

1693 the protomédico of the island kingdom of Sardinia confirmed the opinion of the médico of the galleys, which were then at Naples, that the oarsmen were in a poor state of health. ${ }^{80}$ Important garrisons, including Ceuta and Melilla, ${ }^{81}$ had their own hospitals, although in 1695-96, some at least of the Portuguese troops who had fallen ill at Ceuta were also cared for in the hospitals of that other important fortress, Gibraltar. ${ }^{82}$ Each unit would also have what we might call an unofficial, or informal female nursing staff in the form of the prostitutes, wives and so on, who accompanied the troops and supplied them with a variety of services. ${ }^{83}$

The troops also enjoyed supra-regimental provision, above all in the form of hospitals which catered for the entire army or fleet. The troops of the Army of Flanders in the later sixteenth and early seventeenth centuries could resort either to local charitable institutions or to a special army hospital established at Mechelen in 1585, which in 1637 had 330 beds. ${ }^{84}$ As for the Army of Catalonia, where a lack of effective medical facilities was evident in the early stages of the war against France (from 1635), ${ }^{85}$ the Casa or Hospital de la Misericordia- a typical Counter-Reformation poor relief institution which had also functioned as a royal military hospital during that conflict (until 1659)—-had been handed back to the city authorities in 1663 in return for a promise that soldiers would be cared for in the general hospital, the Santa Cruz. This provision was supplemented by the existence of other royal military hospitals in the fortresses of Gerona, Palamós and Rosas. ${ }^{86}$

As for the fleet, from 1630 the crews of the galleys of Spain had enjoyed the facilities of a new hospital at Puerto de Santa María on Spain's Atlantic coast. ${ }^{87}$ However, the transfer of the galleys in 1669 to Cartagena, on Spain's Mediterranean coast ${ }^{88}$ made necessary the development of facilities at the new base: in 1674 the queen regent ordered the Council of the Cruzada—which was responsible for the funding of the galleys - to pay 200 ducats

(which influenced the development of that of Spanish Naples), Gentilcore, op. cit., note 13 above, p. 32. There is a substantial literature on the protomedicato of the various realms of the early modern Spanish monarchy. In addition to the work of Lanning, note 11 above, see the various contributions to the monograph volume of Dynamis, 2002, 22: devoted to El tribunal del real protomedicato en la monarquía hispánica, 1593-1808.

${ }^{80} \mathrm{AGS} / \mathrm{E} / 3852 / 17$. The protomédico examined the men bench by bench. He found the troops on board and the sailors fine, but the rowers - crucial to the ship's ability to move - for the most part either convalescent or too weak. For the protomédico of the Armada de las Indias, see Lanning, op. cit., note 11 above, p. 128. Lanning's is the best general study of the system of the protomedicato in the Spanish empire, although it largely ignores Spain itself (and Europe).

${ }^{81}$ Consulta of Council of War, 24 Feb. 1699, AGS/ GA/3125. For the protomédico of the Army of Flanders, 1675, see AGS/E/2280/14.

${ }^{82}$ Consulta of State, 5 July 1695, on report of the Marquis of Valparaíso on the "epidemic" sweeping through the Portuguese troops, AGS/E/4041. See accounts of the paymaster of the garrison of Cádiz and proveedor general of Andalucía, Jan. to April 1696, AGS/CMC/3a/2982/22.

${ }^{83}$ In 1684 the Governor of the Low Countries claimed that his troops constituted not an army but a collection of young people, old men, women and a small number of real soldiers, Marquis of Grana to Charles II, 31 May 1684, Lonchay, et al. (eds), op. cit., note 59 above, p. 449. See also Tallett, op. cit., note 5 above, p. 110, and Grell, op. cit., note 3 above, pp. 258-9.

${ }^{84}$ Parker, op. cit., note 9 above, p. 167. In 1574 mutinous troops in Flanders had demanded a military hospital, so this may have been a response to pressure from "below": ibid., p. 191.

${ }^{85}$ Corteguera, op. cit., note 43 above, p. 145.

${ }^{86}$ Espino López, Catalunya, op. cit., note 14 above, p. 432

${ }^{87}$ Fernández Duro, op. cit., note 64 above, vol. 3, pp. 242-9.

${ }^{88}$ Fernández Duro, op. cit., note 64 above, vol. 3, p. 250. 


\section{Christopher Storrs}

towards the building of the hospital at Cartagena. ${ }^{89}$ The first patients entered the new hospital in the spring of $1675 .{ }^{90}$ The Atlantic fleet had its own hospital at Cádiz, ${ }^{91}$ with a capacity in the 1690 s of about $300 .{ }^{92}$ By the end of the reign, the Cádiz hospital was the lynchpin of a network of hospitals dotted around Andalucia which serviced the fleet. ${ }^{93}$

Exceptionally high rates of sickness might necessitate extraordinary additional measures. In 1684, the unusual extent of illness in the Atlantic fleet at Cádiz made necessary the provision of another 262 beds, plus other essential items, costing a total of 18,000 reales. ${ }^{94}$ Inevitably, war put the greatest strain on these resources and might impose both modifications and additions to the structure just described, as in Sicily in the 1670s. On the eve of the Messina revolt, the forces' hospital facilities on the island revolved around the hospital of Santiago in Palermo. However, once the revolt and the Spanish reconquest had begun, this was seen to be too far from the front; hence another hospital was established at Milazzo, in the convent of the Carmen. But this soon proved insufficient, obliging the authorities to establish additional hospitals in Santa Lucia, and at Belvedere near Milazzo. Yet another hospital was established at Catania, for the southern front. ${ }^{95}$ In 1679 , following the defeat of the Messina rebels, the viceroy of Sicily reformed the existing hospital of Messina (whose use had been denied the Spanish forces during the rebellion) into three salas, or wards, the first of which was to care for the military. ${ }^{96}$ An account of 1681 listed five royal and military hospitals in Sicily: Santiago in Palermo, Milazzo (which had disappeared by 1685), those at Messina and Agusta, and one at Siracusa run by the fathers of the Order of San Juan de Dios. ${ }^{97}$ During the Messina war, the sick of the fleet operating in Sicilian waters were sent to the Neapolitan hospital of San Giacomo, or Santiago, and that of the Incurables, ${ }^{98}$ while additional hospitals were ordered to be set up. ${ }^{99}$

During the Nine Years War (1689-97), too, the existing facilities came under extraordinary pressure, making additional provision necessary. In the summer of 1693 there

\footnotetext{
${ }^{89}$ Queen Regent to Don Antonio de Benavides, Madrid, 20 Nov. 1674, AGS/Cruzada/517; Fernández Duro, op. cit., note 64 above, vol. 3, p. 251.

${ }^{90}$ Fernández Duro, op. cit., note 64 above, vol. 3, p. 251.

${ }^{91}$ Fernández Duro, op. cit., note 64 above, vol. 3, pp. 254-9, prints extracts from the regulations of 1633 for the running of this and other royal hospitals.

${ }^{92}$ Consulta of Junta de Apresto de Armadas, 13 (11) Feb. 1696, AGS/GA/3876.

${ }^{93}$ In 1700 the Duke of Alburquerque requested that sick troops in the castle of Santa Catalina (Cádiz) be admitted to the naval hospital, Don Pedro Fernández de Navarrete to [?], Cádiz, 29 Mar. 1700, AGI/Panamá/ 166 , fol. 263. It was subsequently reported that 1,243 men were assembled in Cádiz and 317 in San Lúcar, many of the former falling ill, and in the hospital of San Juan de Dios, Cádiz, doctors feared an epidemic; it was suggested that the levies should be stopped, consulta of Junta [de Guerra de Indias], 6 April 1700, and Count of la Corzana to [?], Madrid, 5 April 1700, AGI/Panamá/ 166, fols 318-19. Duke of Alburquerque to [?], Puerto de Santa María, 17 May 1700, AGI/Panamá/166, fols
}

533-36v, on march of troops from their quarters in Córdoba, Jaén, Málaga, and in Alburquerque's captaincy general, which together with five companies from Melilla (and including those sick in the hospitals of Cádiz, San Lúcar and Jerez) totalled 2,800 men.

${ }^{94}$ Consulta of Junta de Armadas, 17 Feb. 1684, AGS/GA/3709. See also note 32 above.

${ }^{95}$ According to a contemporary account, this was staffed by an administrator, four brothers of San Juan de Dios, a doctor and two surgeons. The same document, AGS/E/3498/239, mentions an unspecified number of Capuchin nurses, besides one doctor and two surgeons.

${ }_{96}$ Madrid Gazette, sub voce Messina, 9 Feb. 1679 , National Library of Scotland, Astorga Collection.

${ }^{97}$ Ribot García, op. cit., note 15 above, pp. 461-2.

${ }^{98}$ For the hospital of the Incurables (founded in 1519), see Gentilcore, op. cit., note 13 above, pp. 126-8. The hospital of San Giacomo was established c. 1550 by a local confraternity of Spaniards, and had strong links with the (Spanish) military in the realm, although it later also took in the sick poor (civilians), ibid., p. 133.

${ }^{99}$ Ribot García, op. cit., note 15 above, pp. 217-18. 


\section{Sickness and Medical Services in Spain's Armed Forces c. 1665-1700}

were so many sick in the Atlantic fleet that the veedor general (inspector general) ordered the construction of 100 additional beds in the hospital at Cádiz. ${ }^{100}$ In the winters of 1694 95 and of 1695-96, the resources of the naval hospital in this town were further stretched by the presence of the sick of the English and Dutch fleets: 300 English seamen were admitted to the hospital at the end of $1695 .{ }^{101}$ As for the galleys, in early 1695, 400 ill men from these were put on a separate galley because the hospitals were full. ${ }^{102}$ The Army of Catalonia experienced similar problems. In 1673 Barcelona's general hospital had agreed to look after the increased number of military casualties which inevitably accompanied the renewal of hostilities with France; in return the military authorities would provide the soldiers' daily pan de munición as well as a small sum of money. The Nine Years War exacerbated this pressure. The loss of Rosas (1693), and of Gerona and Palamós (1694), with their military hospitals meant that sick and wounded soldiers had to be cared for in Barcelona. The viceroy of Catalonia hoped the city's general hospital would accommodate them, but it could take only thirty to forty of his men. He therefore sought to recover from the city authorities the Hospital de la Misericordia, again without success. ${ }^{103}$

He did secure the cession in 1694 of the Franciscan Convento de Jesús, outside the city walls for use as a military hospital, but it was a poor alternative. Indeed, according to a report prepared by the veedor general in February 1696-one which reveals much about contemporary thinking regarding what we might call the ideal hospital-the convent did more harm than good. According to the veedor, a hospital should be sufficiently spacious both to allow the beds to be laid out in rows, thus enabling the doctors, surgeons and other hospital staff to move freely between them and properly minister to their patients. In addition, each ward should have sufficient windows for proper ventilation-in order to disperse the bad odour from the patients' wounds and admit fresh air-and lighting. The building should also have water. Unfortunately, the convent was completely inappropriate. It had been built for a small community of monks, and comprised small, low, dark and airless cells and dormitories, and narrow cloisters open to the elements. Fitting the soldiers into these was difficult and meant overcrowding, poor access, and a generally dangerous (or unhealthy) atmosphere. The inevitable consequence was a high rate of mortality. Not surprisingly, the soldiers were reluctant to go there, and it was also difficult to find medical staff and others - chaplains, for example - to serve there, and to replace those who had died. The problems created by the layout and structure of the convent were compounded by the lack of adequate bedding. According to the veedor, there were just 533 sheets, 551 blankets, 604 straw palliasses and 407 bolsters or pillows. Much of this bedding was so dirty and decrepit that it carried infection, while there was simply not enough of it to facilitate regular laundering. In sum, the convent hospital was little more than a death trap.

${ }^{100}$ Consulta of Junta de Apresto de Armadas, 17 July 1693 , on the veedor general of the Atlantic fleet to [?], 5 July 1693, AGS/GA/3837. The veedor wanted to appropriate a cargo of wood from France which had been diverted into Cádiz, declaring that this was the best type of wood for the beds and that supplies had been disrupted by the present war.

\footnotetext{
${ }^{101}$ Consulta of Junta de Apresto de Armadas, 13 (11) Feb. 1696, AGS/GA/3876.

${ }^{102}$ Operti to San Tommaso, 25 Feb. 1695, AST/LM/Napoli, m. 5.

${ }^{103}$ Consulta of Council of War, 26 March 1696, and accompanying documents, above all the veedor general to Marquis of Gastañaga, 27 Feb. 1696, Barcelona,
} AGS/GA/3013. 


\section{Christopher Storrs}

The veedor general had a three-pronged solution to these problems - and to the need for separate wards for officers and men. Firstly, he urged the manufacture or purchase of a large amount of new bedding, enough for 1,500 beds, for the existing convent hospital. ${ }^{104}$ Then, since the location of the hospital ruled out further building, the veedor negotiated with the general hospital, which was apparently prepared to take up to 200 soldiers. Since the anticipated number of military patients was expected to be higher, the veedor general successfully urged the general hospital to agree to works which should accommodate a further 200 soldiers, doubling its capacity to a total of 400. Fearing this might still not be sufficient, the veedor general also thought that the authorities of the city of Barcelona should continue to be pressed to return the Hospital de la Misericordia. These were ambitious plans. Unfortunately for the sick and wounded of the Army of Catalonia, the veedor's suggestions had still not been fully implemented by late June-by which time he anticipated the influx into the small convent of 800 sick and wounded, crowding the space and exhausting its beds and bedding. ${ }^{105}$ The main explanation was, undoubtedly, lack of funds.

In wartime, field hospitals were often established to accompany that part of the army which went on campaign between April and October. In September 1690, the vicar general (and administrator) of the hospitals of the Army of Lombardy visited Turin to oversee the field hospital established there for the Spanish troops fighting in Piedmont after the recent defeat at Staffarda. ${ }^{106}$ The needs of the field hospitals were sometimes met at the expense of the existing hospitals away from the front line. In 1695 the vicar general of the Army of Catalonia was accused of more or less stripping the convent Hospital de Jesús of Barcelona of bedding and kitchen utensils in order to supply a field hospital, removing essential equipment and jeopardizing the lives of its patients. ${ }^{107}$ In fact, however, the field hospitals-which were generally small, with limited facilities - often simply passed on the soldiers who came to them to the larger, more distant permanent institutions. ${ }^{108}$ The naval forces had their own version of the field hospital: in the summer of 1694, the thirteen Spanish vessels leaving Cádiz to join the Anglo-Dutch vessels commanded by Admiral Edward Russell included a hospital ship. ${ }^{109}$

Oversight of these hospitals was the responsibility of the vicar general of each of the armies or fleets. ${ }^{110}$ In accordance with the preference for the provision of services by means of asiento, or contract, with independent suppliers, rather than for administración - the direct administration by state officials-provisioning of the hospitals was

\footnotetext{
${ }^{104}$ The veedor also estimated the cost of constructing a bed capable of accommodating two men if necessary, and the appropriate bedding: Relación de las piezas de que se deve componer una cama para el ospittal Real, 27 Feb. 1696, AGS/GA/3013.

${ }^{105}$ Veedor general to Charles II, 26 June 1696, Barcelona, AGS/GA/3013.

${ }^{106}$ Certificó ya el Abad D. Gaspar Casado y Rosales, Turin, 21 Oct. 1690, AGS/E/3413/90.

${ }^{107}$ Consulta of Council of War, 13 Feb. 1696, AGS/GA/3012.
}

${ }^{108}$ Veedor general to Charles II, 26 June 1696 , Barcelona, AGS/GA/3013, on the way the facilities in Barcelona were receiving men from the field hospital.

${ }^{109}$ See list of Spanish ships which left Cádiz, July 1694, National Maritime Museum, Greenwich, Southwell MSS 3, fol. 95 .

${ }^{110}$ This was certified by the veedor general of the Armada, as part of the relación de servicios of Don Juan Guerrero, protomédico of the Atlantic Fleet, Madrid, 23 Sept. 1688, AGS/GA/Servicios/42. 


\section{Sickness and Medical Services in Spain's Armed Forces c. 1665-1700}

generally contracted out. ${ }^{111}$ Typical of the private contractors used in this period was Estevan Andreu, a merchant of Gerona, who supplied food, fuel and lighting to the hospital of that town during the Nine Years War, before its loss in 1694, and who in 1696 successfully bid for the contract to run the military hospital in Barcelona for one year. ${ }^{112}$ Occasional inspections of these hospitals, for example of that of Rosas by the protomédico of the Army of Catalonia in March 1685, sought to ensure that they were being properly run. ${ }^{113}$

The day to day operation of the hospitals depended upon a mayordomo, or general administrator, and various doctors, surgeons, apothecaries and administrators. The careers of these men can be followed in their relaciónes de servicios. Don Juan Guerrero studied medicine at the University of Alcalá, and in 1671 passed the exam qualifying him as protomédico. After experience outside the armed forces, including a stint in plague-dominated Cartagena in 1676, Guerrero served as protomédico of the Atlantic fleet between May 1683 and August 1687 when he was obliged to retire because of his own ill health. ${ }^{114}$ Don Juan José de Fita y Ríos rose from doctor in the hospital of the important fortress of Palamós (1668-74), with a salary of 15 escudos a month, to doctor of the field hospital (1674-75), on a salary of 25 escudos, doctor of the entire Army of Catalonia (1675-90), at 30 escudos, and finally protomédico of the Army of Catalonia (1690/91-97), with a salary of 50 escudos a month. From 1697, he also received a bonus of 1 escudo a month for having served with the garrison of the besieged city of Barcelona that year. ${ }^{115}$ Some individuals might rise to even greater heights, as had happened in the past. ${ }^{116}$

The clergy, and in particular the "hospital" orders, played an important part in the administration of medical services for the armed services. Chief among these latter were the Hospitallers of St John of God, a Counter-Reformation order whose origins lay in the establishment by St John of a hospital in Granada just before his death in 1550. Recognized by Pope Pius V in 1572, the Order, whose members took a special vow to care for the sick, ran nearly 300 hospitals throughout Europe and in the Americas by $1700 .{ }^{117}$ In 1674, at the request of the king, the head of the Hospital de San Juan de Dios in Barcelona sent thirteen

\footnotetext{
${ }^{111}$ The earlier triumph of "privatization" is explored by Thompson, op. cit., note 9 above, pp. 256-73 (and passim).

${ }^{112}$ Tender for contract to run the military hospital of Barcelona by Estevan Andreu of Gerona (previously the contractor for the hospital of Gerona), 8 May 1696 , Barcelona, AGS/GA/3013.

${ }^{113}$ Relación de los servicios del Doctor Don Juan Joseph de Fita y Ríos, Médico de Camara de S.M. y prothomédico del Exército de Cataluna, 4 May 1698, Barcelona, AGS/GM/Servicios/41.

${ }^{114}$ Relación de servicios of Don Juan Guerrero, protomédico of the Atlantic fleet, Madrid, 23 Sept. 1688, AGS/GA/Servicios/42. The contribution to this of the vicario general of the fleet suggests that the protomédico oversaw the cures ordered by doctors and surgeons.
}

\footnotetext{
${ }^{115}$ Relación de los servicios del Doctor Don Juan Joseph de Fita y Ríos, médico de camara de S.M. y prothomédico del Exército de Cataluna, Barcelona, 4 May 1698, AGS/GM/Servicios/41.

${ }^{116}$ Cristóbal Pérez de Herrera served as protomédico of the king's galleys (from 1580) before being appointed (1592) a doctor in Philip II's household: Michel Cavillac, 'Noblesse et ambiguïtés au temps de Cervantes: le cas du docteur Cristóbal Peréz de Herrera (1556?-1620)', Mélanges de la Casa de Velázquez, 1975, 11: 177-212.

${ }^{117}$ Robert Bireley, The refashioning of Catholicism, 1450-1700: a reassessment of the Counter-Reformation, Basingstoke, Macmillan, 1999, p. 36.
} 


\section{Christopher Storrs}

members of his order-most of them surgeons - to the Army of Catalonia. ${ }^{118}$ On Spain's various fleets, shipboard nursing staff often also included members of the Order. ${ }^{119}$ In 1696, during the Nine Years War, one Hospitaller of St John of God, fray Clemente Cazón, served as zirujano mayor - senior or chief surgeon — of a tercio in the Armada, but fell ill at Cartagena when it embarked for Italy. He was later taken prisoner by the north Africans when sailing for Italy after his cure. ${ }^{120}$ From 1697 , following his release, Cazón served as surgeon on various ships of the royal fleet. ${ }^{121}$ Members of other religious orders also helped out, not without reimbursement. During the Nine Years War, the infirmary of the tertiary Order of San Francisco in Madrid allocated eight of its beds for the care of the king's soldiers, in return for 1,000 ducats a year. ${ }^{122}$ Military and naval chaplains, too, played a part in ministering to the sick and wounded. ${ }^{123}$

The rest of the nursing staff-variously described as mozos de quadra, ministros, and servientes - who cared for the sick and wounded under the direction of the doctors are not, unfortunately, fully identified in the papers sent to the Council of War. We know, however, that they included those no longer able to work as oarsmen aboard the galleys: in the summer of 1691, twenty-four slaves who were inhaviles, that is unable to man the oars, served in the hospital. ${ }^{124}$

Not all the sick needed or received hospital treatment, or treatment in military or naval institutions. In 1676 Don Francisco Vélez, captain of cavalry, petitioned the king, saying that, after twenty-eight years service (in Catalonia and Extremadura) he had suffered various illnesses in 1674 which made it impossible for him to continue in the army. He therefore sought an indefinite continuation of his (reformed) officer's salary until he was cured. The Council of War was sympathetic, not least because the petition was accompanied by a supporting surgeon's certificate. The council therefore suggested, and the king agreed, that Don Francisco should continue to receive his salary for a year, in the hope that at the end of that period he could return to the service. ${ }^{125}$ Some others were used to provide second line troops. In the summer of 1692, the Marquis of Leganés, having noticed in a review of the Spanish tercios in the Army of Lombardy that many soldiers were unable to campaign because of age, wounds and so on, formed three companies of these

\footnotetext{
${ }^{118}$ Consulta of Council of War, 7 Oct. 1676, on request from Procurador General, AGS/GA/2436.

${ }^{119}$ Phillips, op. cit., note 9 above, p. 138 .

${ }^{120}$ Consulta of Council of War, 6 July 1696 , on petition from fray Clemente Cazón, AGS/GA/3876.

${ }^{121}$ See certificate issued by the contador principal, or chief accountant, of the Armada del Mar Oceano on behalf of fray Clemente Cazón, AGI/Panamá/181 fol. 505; and permission of the General of the Hospital Order of San Juan de Dios for Cazón to serve with the Armada, as requested by the Count of Fernán Nuñez, Madrid, 8 Oct. 1696, AGI/Panamá/181 fol. 505.

${ }^{122}$ Consulta of Council of War, 3 Oct. 1696, on petition from Order of St John, AGS/GA/GA/3011.

${ }^{123}$ See Phillips, op. cit., note 9 above, p. 138 , for the role of the chaplain aboard the Indies fleet as both administrator in charge of the ship's medicine chest and supervisor of diets for the sick.
}

\footnotetext{
${ }^{124}$ Consulta of State, 15 Oct. 1691, on Count of Santesteban to [?], 20 July 1691, AGS/E/322, 94.

${ }^{125}$ Consulta of Council of War, 13 June 1676, on petition of Don Francisco Vélez, AGS/GA/2348. Similarly, in 1693 Don Diego Quixano, on the Spanish galleys, was allowed leave of absence to cure himself of the ailments from which he suffered and did subsequently return to the king's service, Relación de servicios of Don Diego Quixano, AGS/ GA/3908. That same year Bernave de Corbello, a sailor on the ship Atocha, who had been captured by the French and claimed to have fallen ill while a prisoner of war, petitioned for the grant already made to other sailors and was awarded 100 reales so that he could recuperate and return to the royal service, consulta of [?], 30 Oct. 1693, AGS/GA/ 3837.
} 


\section{Sickness and Medical Services in Spain's Armed Forces c. 1665-1700}

and used them to garrison the key fortresses of Cremona, Novara and Alessandria in the Milanese. ${ }^{126}$ Charles II's forces did not, however, enjoy the prospect of a military hospital such as the Invalides in Paris (completed in 1676), or the Royal Hospital, Chelsea (completed in 1692), as did the subjects respectively of the kings of France and England. ${ }^{127}$

Details about the treatments and medicines are scarce. ${ }^{128}$ However, we know that medicines purchased and issued to the soldiers who served with the Genoese galleys in Spanish service in 1670-71 and 1674-76 included various "syrups" (of lemon and so on), unguents, oils, powders and spirits. ${ }^{129}$ But medicines were not the only means to aid the sick. ${ }^{130}$ Another important aspect of the treatment was, inevitably, the diet. According to a contract agreed in the spring of 1696, those officers and men sent to the royal hospital at Barcelona in the Convento de Jesús were to receive nine ounces of meat a day-six at lunch and three at dinner-cooked and well seasoned with parsley, saffron and vegetables appropriate to the patient (as prescribed by the doctor). Those for whom this was not appropriate would be given chicken or some other substitute. In addition, patients would receive an allowance of wine. ${ }^{131}$

Unfortunately, information about rates of cure are less than satisfactory. Antonio Espino López has calculated death/survival rates for the Hospital de Santa Cruz (Barcelona) during the Nine Years War: there the death rate ranged from a low of just over 5.1 per cent (39 of 763 men) in 1687 (peacetime), to a peak of 14.1 per cent (421 of 2,974 men who entered the hospital) in 1694 (wartime). ${ }^{132}$ There is also some evidence for other institutions scattered among the records of the Council of War. In the autumn of 1696 the Franciscan tertiaries of Madrid, who were seeking payment of the substantial arrears owed to them, produced a certificate, based upon their own records and signed by a royal official. According to this document, in the twelve months between mid-September 1695 and mid-September 1696 the infirmary had cared for a total of 53 soldiers-all of whom had to prove their military record to gain entry - in the eight beds the order allocated to the king's soldiers. In addition, there were said to be 4 men in the infirmary at the time the certificate was prepared. This total of 57 included 7 captains (the highest rank) and

\footnotetext{
${ }^{126}$ Leganés to Charles II, Milan, 4 May 1692, AGS/E/3417/78

${ }^{127}$ Anderson, op. cit., note 6 above, pp. 108-9.

${ }^{128}$ For earlier periods, see Goodman, op. cit., note 9 above, pp. 248-9; Parker, op. cit., note 9 above, p. 168; and Phillips, op. cit., note 9 above, pp. 177-80.

${ }^{129}$ See lists of medicines purchased for and consumed and distributed on the Doria galleys, certified by the barbers of the individual vessels, AGS/ Galeras/17, f. fols 92-9, 673 (1670-71), and fols 499-500, 506, 529, 595 (1674-76). Since these are essentially accounts, they give only the cost of items used and no indication of the real quantity. See also the details of medicines sent to the Indies from Seville and Cádiz, between 1650 and 1700, in Lutgardo García Fuentes, El comercio español con América,
} 1650-1700, Seville, Diputación Provincial de Sevilla and Escuela de Estudios Hispano-Americanos de Sevilla, 1980, pp. 317-19, 547-51.

${ }^{130}$ I ignore the resort to spiritual remedies, such as religious processions and so on, for which see $\mathrm{L} \mathrm{J}$ Andrew Villalón, 'Putting Don Carlos together again: treatment of a head injury in sixteenth-century Spain', Sixteenth Century Journal, 1995, 26: 347-65, p. 356.

${ }^{131}$ See contract to supply provisions for those officers and men sent to the Convento de Jesús hospital of Barcelona agreed with Estevan Andreu of Gerona, 8 May 1696, Barcelona, AGS/GA/3013; and Espino López, Catalunya, op. cit., note 14 above, p. 225n40. For an earlier period, see Phillips, op. cit., note 9 above, pp. 177-80.

${ }^{132}$ Espino López, Catalunya, op. cit., note 14 above, p. 225; Espino López, 'Enfermedad y muerte', op. cit., note 14 above, pp. 436-43. 


\section{Christopher Storrs}

33 simple soldiers, the single largest category. Two of the latter had been cared for in the Franciscan infirmary twice. Of the 53 soldiers who had been treated hitherto, 10 had died, a rate of 17.5 per cent. ${ }^{133}$

Besides looking after those who were already sick, efforts were also made to prevent the troops from falling ill in the first place. Individual commanders were wary of allowing infected men to come into contact with their own. ${ }^{134}$ Everywhere, military regulations generally included orders regarding hygiene; they also sought to get rid of the prostitutes and other camp followers who spread venereal infections. ${ }^{135}$ In late seventeenth-century Spain, recruiting captains were often instructed not to accept as recruits young men with contagious infections, ${ }^{136}$ although the difficulty in raising men no doubt meant that many captains welcomed anybody and everybody who came forward. In Spain itself, there was frequently an interruption of campaigning at the height of summer, when it was simply too hot (and when to campaign risked losing men). ${ }^{137}$ Some effort was also made to fit recruits to the theatres in which they were to serve: Galicia in the north-west, with its wet climate, continued to be regarded as an ideal recruiting ground for Flanders since men levied there would adapt more easily to the rainy Low Countries. ${ }^{138}$

This was not all. In the winter of 1692-93, in the course of discussion in the Council of War about the levy of 1,800 men in Spain, for Flanders, it was urged that instead of holding the men raised until the entire force had been levied and then sending them en bloc to Flanders, those recruited should be sent in batches of 400 to 500. One of the arguments advanced in favour of this was that it would prevent illness. ${ }^{139}$ A concern for the health of the troops and their subsequent effectiveness also influenced army operations. In 1692, as the campaign drew to a close, the Council of State was unwilling to allow units of the Army of Lombardy to spend the winter in Dauphiné because it feared the impact on the health (and numbers) of the troops, particularly given the lack of means (i.e. funds) and Dauphiné's inability to support the troops. ${ }^{140}$ Other preventive measures included the provision of tents, to protect the men against the elements while on campaign. In

${ }^{133}$ Consulta of Council of War, 3 Oct. 1696, on petition from the Order of the Franciscans, and enclosed relación, AGS/GA/3011. The fate of the four remaining soldiers is unclear.

${ }^{134}$ In 1664 the Duke of Tursi feared that sick troops embarked on his galleys would infect his crews, Don Carlo Doria Carretto to Don Pedro Fernández del Campo, Barcelona, 25 Mar. 1664, AGS/E/3611/123.

${ }^{135}$ Tallett, op. cit., note 5 above, pp. 107, 124, $132-3$.

${ }^{136}$ See Instrucción que se a de observar en la formazión de las diez companias de infantes que se an de levantar por los capitanes que bienen de Flandes para reclutar los tercios de españoles que sirven en aquellos estados; and Instrucción que se ha de observar por el señor presidente de la chancillería de Valladolid en la formacion y leva de las companias que se han de levantar en la dha ciudad por los capitanes que vienen de Flandes, AGS/GA/2916.
${ }^{137}$ For the persistence of this practice after 1700 , see Henry Kamen, Felipe V: el rey que reinó dos veces, Madrid, Temas de Hoy, 2000, p. 55 (1704).

${ }^{138}$ Manuel María de Artaza, Rey, reino y representación: la Junta General del reino de Galicia, Madrid, Consejo Superior de Investigaciones Cientificas, 1998, p. 282. Although Artaza's evidence is from 1702, such opinions were expressed earlier. One former army administrator, who presumably knew what he was talking about, also believed that, because

Galicia was poor, its population made good soldiers because they could survive on very little, Juan Alfonso de Lancina, Comentarios politicos, Madrid, 1689, ed. José Antonio Maravall, Madrid, 1945, p. 63.

${ }^{139}$ Consulta of Council of War, 11 Feb. 1693, AGS/ $\mathrm{E} / 3887$. The other reasons were to avoid expense and desertion.

${ }^{140}$ Consulta of State, 25 Sept. 1692, on Leganés to Charles II, 5 Sept. 1692, AGS/E/3417/96 and Consulta of State, 30 Oct. 1692 on Leganés to Charles II, 4 and 12 Oct. 1692, AGS/E/3417/105, 106 and 109. 


\section{Sickness and Medical Services in Spain's Armed Forces c. 1665-1700}

1692, the Marquis of Leganés ordered the purchase of material for the making of tents, 100 for the infantry and 65 for the cavalry of the Army of Lombardy, in preparation for the invasion of Dauphiné. ${ }^{141}$ The following year, the Admiral of Castile declared to his colleagues in the junta of the lieutenants-general, a sort of war cabinet that operated between 1693 and 1695, that the provision of tents was one of the most essential and necessary services in any army and claimed to have introduced the use of tents into the Army of Lombardy when he was governor and captain-general of Milan (1678-86). The other members of the junta agreed and suggested that the king order the manufacture of 2,500 tents for the 12,500 infantry - that is one tent for five men-and 1,200 tents for the cavalry of the Army of Catalonia for the next (1694) campaign. Unfortunately, it is not clear whether the king implemented the suggestion: his response suggested that he was concerned to know the cost before taking it further. ${ }^{142}$

\section{The Main Problem: Shortage of Funds}

Medical provision in Spain's armies and navies did not always work well. Medicines might often be lacking, exhausted by extraordinary demand. In 1684, according to the vicar general of the Army of Catalonia, 700 men died in the hospital of Gerona for want of medicines - and because of the mutual infection of men sharing the beds. ${ }^{143}$ The ability to despatch urgently needed medical supplies, for example to Oran in $1696,{ }^{144}$ was made easier by the fact that the western Mediterranean was a "Spanish lake", ringed by Spain and its possessions in Italy and dotted with Spanish islands: the galleys could always put in at a friendly port and request fresh supplies of medicine, as did the Duke of Nájera at Naples in December 1695. ${ }^{145}$ Nevertheless, men sometimes died for want of proper treatment. Other problems included the failure of commanders and officials to co-operate in the care and cure of the sick. In 1684 the Count of Aguilar, commander of the Atlantic fleet, complained at the failure of the authorities in Cartagena to provide for more than 400 sick aboard his vessels: the governor, he claimed, had granted him just three days supply of meat and medicines. ${ }^{146}$

But the fundamental problem was lack of funds, the besetting difficulty of Habsburg Spain. It is widely held that Spain retreated from its imperial commitments in this period, not least because of the cost and the desire to relieve the king's hard pressed Castilian subjects of a fiscal burden which had increased enormously under Philip IV (1621-65), but

\footnotetext{
${ }^{141}$ Consulta of Council of Italy, 16 Nov. 1692, on Leganés to [?], 8 Aug. 1692, AGS/E/3417/175.

${ }^{142}$ Consulta of Junta of Lieutenants-General, 30 Dec. 1693, AGS/GA/2913. I have searched succeeding legajos without success to discover the outcome of this proposal; this amply demonstrates the difficulties facing the researcher seeking to use the voluminous Council of War series. The introduction and generalization throughout Europe's armies of such practical (health-preserving) measures as field tents awaits proper study.

${ }^{143}$ Don Damián Caro to López de Zarate, 12 Aug. 1684, AGS/GA/2610, cited by Espino López, Catalunya, op. cit., note 14 above, p. 61.
}

\footnotetext{
${ }^{144}$ Consulta of Council of War, 6 Feb. 1696, on report from one of the royal boticarios, AGS/GA/ 3012. The cost of these medicines, sent from the royal botica, totalled 12,780 reales (including packaging). Their weight-500 arrobas (about $5,750 \mathrm{~kg}$ )-however meant that it cost a further 500 reales to transport the medicines to Cartagena from Madrid.

${ }^{145}$ Duke of Nájera to [Charles II?], Naples, 25 Feb. 1695, AGS/E, leg. 3326/17.

${ }^{146}$ Consulta of Junta de Armadas, 28 Jan. 1684, on letter from Count of Aguilar, Cartagena, 22 Jan. 1684, AGS/GA/2608.
} 


\section{Christopher Storrs}

which was much harder to bear in a period of economic downturn. ${ }^{147}$ The reign of Charles II certainly saw some relaxation of the demands imposed on the king's subjects. ${ }^{148}$ However, the king and his ministers remained committed to the preservation of the monarchy, and in 1695, for example, imposed what was in effect a new salt tax at the height of the Nine Years War to fund imperial defence. ${ }^{149}$ Nevertheless, the cost of war frequently outstripped the funds available to Charles II and his ministers, ${ }^{150}$ and the king's armies and navies suffered in consequence.

Hospitals and medical provision absorbed a tiny proportion of military spending. This, too, is a subject difficult to penetrate, given the paucity of budgets and the complexity and delay of Spanish accounting procedures. Nevertheless, some data is available. In the winter of 1676-77 it was claimed that the Army of Catalonia needed regular payments of 115,219 escudos a month. Of these the hospitals took only 4,000 escudos a month (whereas fortifications took 10,000 and the pay of 43,000 infantrymen and 4,000 cavalrymen just under 60,000 escudos). ${ }^{151}$ In general, medical services represented a very small proportion of total army spending, as in the past. ${ }^{152}$ In 1697, the Marquis of Leganés claimed that the Army of Lombardy needed just 20,000 escudos (a little over 3.5 per cent) for hospitals out of a total of 590,000 escudos. ${ }^{153}$ The galley fleets conformed to this pattern too. Expenditure on medicines on one of the galleys of the Duke of Tursi totalled 175 Genoese libras, just over 1 per cent of a total expenditure of 16,973 libras. ${ }^{154}$ Sometimes these services absorbed a lesser proportion. In 1693, when calculating the costs of a levy of 1,000 men in the realm of Galicia for Flanders, the captain-general included medicines, the salaries of doctors, surgeons and others serving in the hospitals, totalling 12,000 reales (just over 2.1 per cent) of a total bill of 549,540 reales. ${ }^{155}$ But on occasion medical provision was more expensive. In the winter of 1677 , the cost of hospitals within Spain (for its garrisons) for 1678 was budgeted at 52,012 escudos, just under 10 per cent of

\footnotetext{
${ }^{147}$ According to I A A Thompson, “"Money, money, and yet more money!" Finance, the fiscal-state and the military revolution: Spain 1500-1650', in Rogers (ed.), op. cit., note 2 above, pp. 273-98, on p. 287, Charles II's reign "saw the collapse of interna authority, a tax-freeze, and the retreat of Spain from hegemonic conflict. The three were closely interrelated".

${ }^{148}$ Juan Antonio Sánchez Belén, La política fiscal en Castilla durante el reinado de Carlos II, Madrid, Siglo XXI de España, 1996, pp. 213-56.

${ }^{149}$ Julio D Muñoz Rodríguez, Damus ut des: los servicios de la ciudad de Murcia a la corona a finales del siglo XVII, Murcia, Real Academia Alfonso X el Sabio, 2003, pp. 129-32.

${ }^{150}$ Spain's financial difficulties in this period are explored by Manuel Garzón Pareja, La hacienda de Carlos II, Madrid, Instituto de Estudios Fiscales, 1980, and Sánchez Belén, op. cit., note 148 above.

${ }^{151}$ Consulta of Council of War, 12 Jan. 1676, AGS/ $\mathrm{GA} / 2353$
}

${ }^{152}$ Between 1634 and 1641 the military hospital of the Army of Flanders, with its 330 beds, represented 1 per cent of the expenditure of the Army of Flanders, Parker, op. cit. note 9 above, p. 167n3.

${ }^{153}$ Consulta of State, 21 Oct. 1696 on Leganés's report of costs, AGS/E/3423/163, 164. The largest sums were for the bread supply (180,000 escudos) and the Artillery Train (100,000 escudos).

${ }^{154}$ Report of Alessandro and Estevan Doria, and attached certificate, [1691], AGS/Comisaria de Cruzada/365.

${ }^{155}$ Consulta of Junta of Lieutenants-General, 15 Nov. 1693, on Count of Palma to [?], Coruña, 31 Oct. 1693 and enclosed Gastos de una leva de mil hombres para Flandes, AGS/GA/2916. The real was equivalent to 34 maravedis, and the escudo to 340 maravedis. Thus, one escudo was worth 10 reales. Carlos Alvarez Nogal, El crédito de la monarquía hispánica en el reinado de Felipe IV, Valladolid, Junta de Castilla y León, 1997, p. 10. 


\section{Sickness and Medical Services in Spain's Armed Forces c. 1665-1700}

a total defence expenditure of $575,485 .{ }^{156}$ Why expenditure here represented so large a proportion of anticipated costs is unclear, but an unusual increase in the level of illness might mean spending in excess of the sum allocated in advance, ${ }^{157}$ as did the need to provide for the sick aboard the English fleet which wintered at Cádiz between December 1695 and March 1696: it was reported that this cost the town's hospitals an additional 43,712 silver reales. ${ }^{158}$

Small as they were, payments were often long overdue. In July 1676 Don Juan de Gasión, the boticario mayor (chief apothecary or pharmacist) of the Army of Catalonia, petitioned for payment of the fifteen months salary owed to him. ${ }^{159}$ The consequences could be drastic for medical provision. Towards the end of the 1676 campaign, the head of San Juan de Dios, Barcelona, complained at the lack of means to attend to the sick of the Army of Catalonia in the hospital. ${ }^{160}$ These problems, which were exacerbated in wartime, inevitably recurred during the Nine Years War. By August 1693 the general hospital in Barcelona was owed more than 50,000 reales for its treatment of the men of the Army of Catalonia; ${ }^{161}$ and as late as June 1696 , Gasión had no money to prepare the botica, or pharmacy, for the campaign. ${ }^{162}$ More seriously, shortage of funds prevented the full implementation of the proposals of the veedor general to expand and improve military hospital provision in Barcelona: the general hospital refused to go ahead unless the arrears owed to it were paid and the authorities in Madrid advanced the funds for the expansion of the hospital's facilities, while nobody would bid for the contract to make 600 new beds without the promise of a substantial advance. At the same time, inadequate funding of the field hospital meant that it passed on more and more men to the already overburdened and inadequate convent hospital of Jesús. ${ }^{163}$

These problems were not confined to Catalonia. In 1691, the newly-arrived governor of Milan, the Marquis of Leganés, having delayed his departure from Madrid in order to ensure that he went with money to fund his forces, gave just 6,000 ( 2 per cent) of the 300,000 escudos he had brought with him from Spain, for not only hospitals but also the purchase of horses and of clothes for the infantry. ${ }^{164}$ In April 1692, Leganés, who was preparing for the coming campaign, declared that he would have great difficulty if he were not sent money to pay for the hospitals (and the artillery train, bread supply and other campaign necessities). ${ }^{165}$ In October 1695, Leganés complained of the debts he had

${ }^{156}$ Relación de los presidios de España y Africa, considered by Junta de las disposiciones generales, 18 Nov. 1677, AGS/E/1947/212, 213.

${ }^{157}$ Cf. Consulta of Council of War, 19 Oct. 1684, on Duke of [Canizano ?] to [?], 2 Oct. 1684, AGS/ GA/2609.

${ }^{158}$ Consulta of Junta de Apresto de Armadas, 16 (14) April 1696, on letter from the veedor general of the Armada (with a receipt from the mayordomo of the hospital), AGS/GA/3876.

${ }^{159}$ Charles II to Marquis of Zerralvo, 1 July 1676, ordering payment of whatever was owed to Don Juan de Gasión, and prompt payment of his salary in the future, AGS/GA/2360.

${ }^{160}$ Consulta of Council of War, 7 Oct. 1676, on representation of the procurador general, AGS/GA/ 2346 .
${ }^{161}$ Consulta of [?], 22 Aug. 1693, on report from administrator of the hospital, AGS/GA/3013.

${ }^{162}$ Veedor general to Charles II, Barcelona, 26 June 1696, AGS/GA/3013.

${ }^{163}$ Consulta of Council of War, 12 May 1696, AGS/ $\mathrm{GA} / 3013$.

${ }^{164}$ Leganés to Charles II, Milan, 11 June 1691 , AGS/E/3415/17.

${ }^{165}$ Leganés to Charles II, Milan, 11 April 1692, AGS/E/3416/147. Subsequently, Leganés declared that, just two months into the campaign, he must do without the artillery train, hospitals and so on unless urgently helped, Leganés to Charles II, Milan, 17 May 1692, and Noticia de los medios que se han tenido este año y la forma en que se han distribuido, AGS/E/3417/ 23, 24. 


\section{Christopher Storrs}

contracted to pay for-among other things—-the army's hospitals. ${ }^{166}$ The Atlantic fleet also suffered in this way: in the winter of 1684-85 the meat supplier to the hospital of that force at Cádiz was still seeking payment for provisions supplied in 1679-80. ${ }^{167}$ Institutions away from the front, in the capital, did not escape either: the Franciscan tertiaries had to request, in the autumn of $1696,1,000$ ducats due to them for the eight beds they made available in Madrid, and that the sum be assigned on (i.e. paid out of) a more reliable revenue in the future. ${ }^{168}$

The king and his ministers attempted to bridge the funding gap in so far as it affected military and naval hospitals by seeking extraordinary contributions towards the costs of these from the clergy. During the Nine Years War, in the spring of 1691, for example, Charles II sought charitable donations towards the costs of the hospital of the Army of Catalonia from the dean and chapter of the cathedral of Lugo (Galicia), ${ }^{169}$ and other ecclesiastical institutions; and again, in 1693 and 1696 asked various ecclesiastics for help with the funding of the same hospital. ${ }^{170}$ Some, including the bishops of Jaén and Seville in 1693, did contribute. ${ }^{171}$ But not all. In 1691 the dean and chapter of Lugo rejected the king's request, pleading their notorious poverty. For their part, the archbishops of Santiago and Seville, who had agreed some years before that each would give the hospital of the Atlantic fleet at Cádiz 6,000 ducats a year, were said in 1696 to owe considerable arrears-weakening the ability of the hospital to provide adequate medical care. ${ }^{172}$

The ability of Charles II and his ministers to ensure effective medical services in his armed forces was thus undermined by the chronic financial difficulties that had long dogged Spain's armies and navies. ${ }^{173}$ Money to fund services-pay, clothing, food, lodging or cover, transport and so on, which might have prevented the men from falling ill in the first place-was slow to arrive and often insufficient when it did so; the same was true of the funds needed to sustain the medical services once the men had fallen ill.

\section{Conclusion}

It is difficult to compare the numbers of sick and wounded in the Spanish armed forces between 1665 and 1700 and the effectiveness of their treatment either with those in the same forces before 1665 , or with those in the forces of other states in the same period

\footnotetext{
${ }^{166}$ Consulta of State, 12 Nov. 1695, on Leganés to Charles II, Milan, 20 Oct. 1695, AGS/E/3422/122, 123.

${ }^{167}$ Consulta of Junta de Armadas, 1 Feb. 1685, AGS/GA/3709.

${ }^{168}$ Consulta of Council of War, 3 Oct. 1696, on petition from the Order of San Juan, AGS/GA/GA/ 3011.

${ }^{169}$ Dean and chapter of Lugo cathedral to Charles II, 27 May 1691, AGS/E/4171.
}

\footnotetext{
${ }^{170}$ Consulta of Council of War, 27 June 1696, AGS/GA/3013.

${ }^{171}$ [?] to Marquis of Villanueva, 31 March 1693, and [?] to same, 21 April 1693, AGS/GA/2946.

${ }^{172}$ Consultas of Junta de Apresto de Armadas, 5 March and 16 April 1696, AGS/GA/3876. See Antonio Domínguez Ortiz, La sociedad española en el siglo XVII, II: El estamento eclesiástico, Madrid, Consejo Superior de Investigaciones Científicas, 1970, p. 209

${ }^{173}$ Parker, op. cit., note 9 above, p. 132.
} 


\section{Sickness and Medical Services in Spain's Armed Forces c. 1665-1700}

because the necessary research simply has not been done ${ }^{174}$ or because the necessary primary source material does not exist (or has not been discovered). For the same reason, merely comparing rates of sickness and cure between the different forces of Charles II is no easy task. What is clear, however, is that Spain's armed forces, like those of other states, suffered constant attrition from sickness, which on occasion rivalled desertion as the great source of loss of military manpower. The sick and wounded and their treatment were a major concern of Spanish military officials. Loss of men through illness was taken for granted and built into calculations about army strength: in November 1693, it was said that 1,100 men recruited really meant—with losses by flight, ill health and death-1,000 men serving at the front. ${ }^{175}$ While some illnesses were common to civilians and soldiers alike, others were either unique-or nearly so- to the profession of arms or were the consequence of the stresses and strains of military life. The king, his generals and ministers, as we have seen, clearly felt obliged — on both practical and moral grounds— to do something for those in the king's service, a concern echoed in numerous treatises on the conduct of war. ${ }^{176}$ This meant maintaining and-particularly in wartime-expanding medical services developed in earlier reigns, which were an integral part of Spain's role as a military innovator in the "military revolution".

Unfortunately - and despite arguments to the effect that medical science was resurgent in Spain from about $1680^{177}$ — that provision was not always effective in the last decades of Spanish Habsburg rule. The inadequacies of the Spanish military medical services in the late seventeenth century in some respects reflected the difficulties incurred in attempting to face the challenges (in terms, for example, of new types of wound) posed by the "military revolution". In this respect, Spain's failings were by no means unique. However, the extent of illness reflected some of Spain's real difficulties—notably demographic setbacks and their impact on recruitment - while the weaknesses of Spanish military medicine were also the result of that fundamental problem which dogged all aspects of government in late seventeenth-century Spain, lack of money. Shortage of funds, often the indirect cause of sickness among the troops, also had the inevitable consequence that many of those who did fall ill, or who were wounded, received poor treatment and even died. In some respects little had changed since the reign of Philip II when, as David Goodman has observed, war stimulated the provision of medical care for the king's troops but also exhausted the funds necessary to make that care effective. ${ }^{178}$

\footnotetext{
${ }^{174}$ John A Lynn, Giant of the grand siècle: the French army, 1610-1715, Cambridge University Press, 1997, pp. 420-6, the most recent survey of the French army in the seventeenth century provides an excellent account of the development of medical services within that force but gives no figures regarding the extent of the problem or rates of cure.

${ }^{175}$ Consulta of Council of War, 18 Nov. 1693 , AGS/GA/2916.
}

\footnotetext{
${ }^{176}$ F Dávila Orejón Gastón, Politica y mecánica militar para sargento mayor de tercio, Madrid, 1669, p. 195, urged the victorious commander to ensure the despatch to hospitals of his wounded after any battle.

${ }^{177}$ See Henry Kamen, Spain in the later seventeenth century 1665-1700, Harlow, Longman, 1980, pp. 322-4.

${ }^{178}$ Goodman, op. cit., note 9 above, p. 250.
} 


\section{Christopher Storrs}

International comparisons are not easy, but medical provision in the Spanish armed forces was probably better than that of England (at least before the War of the Spanish Succession, when the English government began to respond more effectively to the challenge of sustained continental conflict from 1689), though inferior to that of the Dutch Republic ${ }^{179}$ and to that of Spain's main competitor between 1665 and 1700, France. ${ }^{180}$

The advent of the new Bourbon dynasty in Spain in 1700, in the person of Louis XIV's grandson, Philip V, and the introduction of French methods, ${ }^{181}$ seems to have inaugurated a period of improvement in this sphere of government activity, as in many others: this was exemplified in new instructions for the organization and operation of military hospitals in 1708 during the War of the Spanish Succession. ${ }^{182}$ Nevertheless, long after 1700 the sick and wounded remained as serious a threat to the effectiveness of the armies and navies of Bourbon Spain as they had been to its Habsburg predecessor, ${ }^{183}$ and their treatment a major challenge to the Spanish authorities' ability to provide effective medical services for their troops. ${ }^{184}$

${ }^{179}$ See the English and Dutch medical provision for their forces in Flanders in the Nine Years War as outlined by John Childs, The British army of William III 1689-1702, Manchester University Press, 1987, pp. 157-9; and hospital services in the contemporary English navy, as surveyed in John Ehrman, The navy in the war of William III, 1689-1697, Cambridge University Press, 1953, pp. 126-7, 441-5. For English provision in the War of the Spanish Succession, see Steele, and Gask, both op. cit., note 4 above. Unfortunately, E Gruber von Arni, Hospital care and the British standing army, 1660-1714, Aldershot, Ashgate, 2006, appeared too late for consultation.

${ }^{180}$ However, we should not ignore the defects of French army medical services in this period, see Rowlands, op. cit., note 4 above, pp. 97-8, 227.

${ }^{181}$ Henry Kamen, The war of succession in Spain 1700-1715, London, Weidenfeld and Nicolson, 1969, pp. 42-56; and Concepción de Castro, A la sombra de Felipe $V$ : José de Grimaldo, ministro responsable (1703-1726), Madrid, Marcial Pons, 2004, passim.
${ }^{182}$ AGS/Secretaría de Guerra/Suplemento/269 (Hospitales, 1713-70).

${ }^{183}$ When Tortona (north Italy) surrendered to the forces of the King of Sardinia in 1746, during the War of the Austrian Succession, the Spanish troops in the garrison there totalled 3,384. Of these, 303 were already in hospital and another 17 required hospitalization, a total of nearly 10 per cent, see table in AST/Materie Militari/Imprese Militari, m. $6 / 9$.

${ }^{184}$ In 1721 the Marquis of Tolosa, Secretary of State for War, the Navy and the Indies, was arrested for his links with the company that had the contract to provision the Spanish army in north Africa, and which had supplied food of such poor quality that on returning to Spain the sick soldiers had filled the hospitals of Andalucía: Santos Madrazo, Estado débil y ladrones poderosos en la España del siglo XVIII: historia de un peculado en el reinado de Felipe $V$, Madrid, Catarata, 2000 , p. 69. 